\title{
GENERIC AGING MANAGEMENT PROGRAMS FOR LICENSE REWEWAL OF BWR REACTOR COOLANT SYSTEMS COMPONENTS
}

\author{
$\underline{\text { V. N. Shah and Y.Y. Liu }}$ \\ Argonne National Laboratory \\ Argonne, Illinois 60439 \\ USA \\ $630252-5848$
}

\begin{abstract}
The submitted manuscript has been created by the
University of Chicago as Operator of Argonne

National Laboratory (ÒArgonneÓ) under Contract No.

W-31-109-ENG-38 with the U.S. Department of

Energy. The U.S. Government retains for itself, and

others acting on its behalf, a paid-up, nonexclusive,

irrevocable worldwide license in said article to

reproduce, prepare derivative works, distribute copies

to the public, and perform publicly and display

publicly, by or on behalf of the Government.
\end{abstract}

For presentation at the $10^{\text {th }}$ International Conference on Nuclear Engineering (ICONE 10), in Arlington, Virginia, April 14-18, 2002

Work supported by U. S. Department of Energy under Contract W-31-109-ENG-38. 


\title{
GENERIC AGING MANAGEMENT PROGRAMS FOR LICENSE RENEWAL OF BWR REACTOR COOLANT SYSTEM COMPONENTS ${ }^{1}$
}

\author{
V. N. Shah ${ }^{2}$ and Y. Y. Liu \\ Energy Technology Division \\ Argonne National Laboratory \\ Argonne IL 60439
}

\begin{abstract}
The paper reviews the existing generic aging management programs (AMPs) for the reactor coolant system (RCS) components in boiling water reactors (BWRs), including the reactor pressure vessel and internals, the reactor recirculation system, and the connected piping. These programs have been evaluated in the U.S. Nuclear Regulatory Commission (NRC) report, Generic Aging Lessons Learned (GALL), NUREG-1801, for their use in the license renewal process to manage several aging effects, including loss of material, crack initiation and growth, loss of fracture toughness, loss of preload, wall thinning, and cumulative fatigue damage. The program evaluation includes a review of ten attributes (scope of program, preventive actions, parameters monitored/inspected, detection of aging effects, monitoring and trending, acceptance criteria, corrective actions, confirmative process, administrative control, and operating experience) for their effectiveness in managing a specific aging effect in a given component(s). The generic programs are based on the ASME Section XI inservice inspection requirements; industry guidelines for inspection and evaluation of aging effects in BWR reactor vessel, internals, and recirculation piping; monitoring and control of BWR water chemistry; and operating experience as reported in the USNRC generic communications and industry reports. The review concludes that all generic AMPs are acceptable for managing aging effects in BWR RCS components during an extended period of operation and do not need further evaluation. However, the plantspecific programs for managing aging in certain RCS components during an extended period of operation do require further evaluation. For some plant-specific AMPs, the GALL report recommends an aging management activity to verify their effectiveness. An example of such an activity is a one-time inspection of Class 1 small-bore piping to ensure that service-induced weld cracking is not occurring in the piping. Several of the AMPs, which do not require further evaluation, do need enhancements to allow for an extended period of reactor operation. The paper concludes that the GALL report systematically evaluates the generic AMPs for their effectiveness during an extended period of operation and provides a technical basis for their acceptance. The use of the GALL report should facilitate both preparation of a license renewal application and timely and uniform review by the NRC staff.
\end{abstract}

\section{INTRODUCTION}

Licensees of the U.S. nuclear power plants have developed programs for managing aging in plant systems, structures, and components during the initial license period. Many of the existing aging management programs (AMPs) have been found to be effective and have been approved by the NRC staff. It is thus reasonable to expect that the existing programs could also be effective in managing aging during plant's extended operation and may be employed during license renewal. Our review of several license renewal applications indicates that most of the AMPs that are credited for license renewal are the existing programs.

Many of these existing AMPs are generically similar and need to be evaluated only once for their effectiveness during license renewal. This evaluation would identify (1) the conditions under which existing programs are considered adequate to manage identified aging effects without change, and (2) the conditions under which existing programs should be augmented for this purpose. Since the U.S. licensees are expected to submit license renewal applications for many nuclear power plants, the evaluation of generic AMPs would make the review of the license renewal applications more efficient by avoiding the repeated evaluation of similar programs.

The NRC staff has reviewed the existing generic AMPs with the technical assistance of Argonne National Laboratory and Brookhaven National Laboratory. The staff reviewed the aging effects on components and structures, identified the relevant existing programs, and evaluated program attributes to manage aging effects for license renewal. The results of this review are published in a report, Generic Aging Lessons Learned (GALL) Report, NUREG-1801 (USNRC 2001a). The components and structures addressed in the GALL report are passive and long-lived and are within the scope of license renewal as defined by Title 10 of the Code of Federal Regulations Part 54 (10 CFR 54 2000). The report provides a technical basis for crediting existing AMPs at both boiling water reactor (BWR) and pressurized water reactor (PWR) plants and recommending areas for program augmentation and further evaluation. The experience of the staff members who reviewed the initial license renewal applications was considered in preparing the report. Technical experts from the nuclear

\footnotetext{
${ }^{1}$ Work supported by U.S. Department of Energy under Contract W-31-109-ENG-38.

${ }^{2}$ Contacting author. Tel. No. (630) 252-5848; E-mail address: vnshah@anl.gov
} 
industry and other stakeholders also participated in developing and reviewing the report.

The Standard Review Plan for Review of License Renewal Applications for Nuclear Power Plants (SRP-LR), NUREG-1800, provides guidance to staff reviewers for performing safety reviews of applications to renew nuclear power plant licenses in accordance with 10 CFR 54 (USNRC 2001b). The GALL report is a technical-basis document to the SRP-LR. The main objectives of SPR-LR are to ensure the quality and uniformity of staff reviews and to present a well-defined base from which to evaluate the applicant's programs and activities for the period of extended operation.

A license renewal application may reference the GALL report to demonstrate that the programs at the applicant's facility correspond to those reviewed and approved in the GALL report and, therefore, no further staff review is required. Instead of further review, the staff would ensure that the approvals set forth in the GALL report for generic AMPs apply to the applicant's programs. The staff review would then focus on those programs that are being augmented for license renewal and on the information that is not addressed in the GALL report or is otherwise different from that in the GALL report. The applicant is not required to use the GALL report, but its use should facilitate both preparation of a license renewal application and its timely and uniform review by the NRC staff.

The paper reviews the existing generic AMPs for the components in the BWR reactor coolant system (RCS) evaluated in the GALL report. The components include the reactor pressure vessel and internals and the RCS piping. The vessel internals include, for example, the core shroud and core plate, core spray lines and spargers, jet pump assemblies, fuel supports, and instrument housings. The RCS piping includes the reactor recirculation system and portions of the other systems connected to the pressure vessel and recirculation piping extending to the second containment isolation valve outside the containment. The connected systems include, for example, the residual heat removal, low-pressure and high-pressure core spray, feedwater, and isolation condenser systems. The intended function of the reactor pressure vessel components, as well as penetrations and RCS piping, is to provide a pressure-retaining boundary so that sufficient flow of coolant at adequate pressure is delivered. The intended functions for the vessel internals are to provide structural support to safety-related components such as the core shroud, help maintain fuel alignment to ensure that the control rods can be inserted into the core, direct the flow of reactor coolant through the core, provide a flow path to the core cooling water, and maintain the coolant level in the core following a loss-of-coolant accident.

The paper discusses the applicable aging effects for the BWR RCS components, reviews the existing generic AMPs for managing these effects, and assesses the adequacy of the program attributes for license renewal.

\section{APPLICABLE AGING EFFECTS}

Applicable aging effects are determined from operating experience documented in numerous NRC licensee event reports (LERs), NRC and vendor generic communications, NUREG reports, industry and Electric Power Research Institute (EPRI) reports. A summary of the various aging effects and mechanisms identified for the structures and components in the reactor pressure vessel, reactor vessel internals, and primary coolant pressure boundary have been given in NUREG-1557 (USNRC 1996a). The aging effects for the
BWR RCS components evaluated in the GALL report include crack initiation and growth, loss of material, wall thinning, loss of fracture toughness, cumulative fatigue damage, and loss of preload.

Specific aging effects resulting from an abnormal event need not be addressed for license renewal of a given plant, unless the event occurred at that plant. In that case, the contribution of the event to aging effects on structures and components that are within the scope of license renewal should be considered. It should be noted that if operating experience or other information indicates that a certain aging effect is applicable but an applicant determines that this effect is not applicable to its plant, then the applicant should provide a technical basis for this assessment.

\section{GENERIC AGING MANAGEMENT PROGRAMS FOR LICENSE RENEWAL}

Aging management programs are generally of four types: prevention, mitigation, condition monitoring, and performance monitoring (USNRC 2001b). Prevention programs preclude the effects of aging. For example, surface coating of carbon steel piping prevents loss of material due to external corrosion. Mitigation programs attempt to slow the effects of aging. A water chemistry program, for example, retards loss of material due to internal corrosion of piping components. Condition monitoring programs inspect for the presence and extent of aging effects. The ASME Section XI inservice inspection (ISI) program, for example, provides for detection and sizing of cracks in the reactor coolant system components. Performance monitoring programs assess the ability of a component to perform its intended function. For example, heat-transfer capability testing is an effective means to assess the surface condition of heat exchanger tubes in the service water system.

The generic AMPs reviewed in this paper are either mitigation programs or condition monitoring programs. More than one type of program may be needed for effective management of an aging effect. In the management of crack initiation and growth in reactor coolant system components, for example, a water chemistry program, which is a mitigation program, is employed along with an ISI program, which is a condition monitoring program.

\section{Program Attributes}

As described in the SRP-LR (USNRC 2001b), an acceptable AMP should consist of all or some of the ten attributes listed below. If more than one AMP are needed to manage a certain aging effect, these AMPs may be evaluated together for the 10 attributes. Probabilistic risk assessments may be used to develop the details of an AMP, but these assessments alone cannot be used to conclude that no aging management program is necessary for license renewal.

(1) Scope of Program. The scope of the program should identify the structures and components for which an aging effect is being managed.

(2) Preventive Actions. The activities of a prevention or mitigation program should prevent or mitigate a given aging effect. The condition and performance monitoring programs do not include such activities.

(3) Parameters Monitored/Inspected. Parameters monitored or inspected should be linked to degradation of a specific intended function of one or more components within the program scope. For mitigation programs, for example, the specific parameters that control the mitigative activities should be monitored. 
(4) Detection of Aging Effects. Detection of aging effects should occur before there is a loss of intended function for structures or components. This attribute should include method or technique (e.g., visual, volumetric, surface inspection), frequency, sample size, data collection, and timing of inspection to ensure timely detection of aging effects.

(5) Monitoring and Trending. Monitoring and trending should provide for predictability of the extent of aging damage, and timely corrective or mitigative actions.

(6) Acceptance Criteria. The acceptance criteria, against which the need for corrective action will be evaluated, should ensure that the intended functions of structures and components are maintained under all current licensing basis (CLB) design conditions during the period of extended operation.

(7) Corrective Actions. Corrective actions should be timely and include determination of root causes and prevention of recurrence. If corrective actions permit analysis without repair or replacement, the analysis should ensure that the intended function(s) of structure and component would be maintained consistent with the CLB during the extended period of operation.

(8) Confirmation Process. Confirmation process should ensure that the preventive actions are adequate and that corrective actions are effective.

(9) Administrative Controls. Administrative controls should provide for a formal review and approval process.

(10) Operating Experience. Operating experience of the AMP, including past corrective actions resulting in program enhancement or additional programs, should provide objective evidence to support the conclusion that the aging effects will be managed adequately so that the intended function(s) of the structure and component will be maintained consistent with the CLB during the period of extended operation.

The programs evaluated in the GALL report are based on a comprehensive review of the operating experience prior to April 2001, which is the manuscript completion date for the GALL report. If operating experience after this date identifies an aging effect at a new location of a structure or component, i.e., a location, which has experienced this aging effect for the first time, then the AMP to manage this effect needs to be modified.

The AMPs evaluated in the GALL report for the BWR RCS components may be divided into those generic AMPs that do not require further evaluation, and those plant-specific AMPs that do require further evaluation. Also requiring no further evaluation is an optional AMP for managing metal fatigue of reactor pressure boundary components, considering environmental effects, less than 10 CFR54.21(c)(1)(iii).

\section{Generic Aging Management Programs}

The GALL report evaluated 13 generic AMPs that are acceptable for managing aging effects in the BWR RCS components. These programs may be divided into five groups, as follows:

Group I. General Programs

ASME Section XI In-service Inspection (ISI), Subsections IWB, IWC, and IWD

Water chemistry

Group II. Programs for Reactor Vessel Components

Reactor head closure studs
BWR feedwater nozzle

BWR control rod drive return line (CRDRL) nozzle

Group III. Programs for Austenitic Stainless Steel Components

BWR vessel inside diameter (ID) attachment welds

BWR stress corrosion cracking (SCC)

BWR penetrations

BWR vessel internals

Group IV. Programs for CASS Components

Thermal aging embrittlement of cast austenitic stainless steel (CASS)

Thermal aging and neutron irradiation embrittlement of CASS

Group V. Programs for Carbon Steel Piping and Closure Bolting Flow-accelerated corrosion

Bolting integrity

The two programs in Group I address management of aging effects in most of the BWR RCS components and are recommended along with other AMPs. The first program is a condition-monitoring program, whereas the second program is a mitigation program. The programs in Group II address managing loss of material and cracking in the components of low-alloy steel reactor pressure vessels. The programs in Group III refer to inspection and evaluation guidelines provided in the Boiling Water Reactor Vessel and Internals Project (BWRVIP) documents to manage crack initiation and growth due to stress corrosion cracking in the austenitic stainless steel RCS components. The programs in Group IV address managing loss of fracture toughness in the CASS RCS components. The programs in Group V address managing loss of material, cracking, and loss of preload in carbon steel piping and pressure retaining bolting. Some of these programs have been enhanced to manage a specific aging effect in a given component in an acceptable manner. The salient points of each of these programs are summarized next. No attempt has been made to summarize all 10 attributes of a given program.

General Programs. The ASME Section XI program in accordance with Subsections IWB, IWC, or IWD has been generally shown to be effective in managing aging effects in Class 1,2 , or 3 components and their integral attachments in light water cooled power plants (ASME 1995). The Section XI ISI requirements, however, are to be augmented to manage aging effects in several components during extended operation. The augmented inspection for each of these components, except the welded access hole cover, is incorporated in a specific AMP described later. Visual inspection of the access hole cover weld, as required by Section XI, is not adequate to detect cracking initiated in the crevice region (USNRC 1988b, 1992). The augmented inspection is to include ultrasonic examination or other demonstrated acceptable inspection of the access hole cover welds.

The water chemistry program is based on EPRI guidelines and is credited for managing loss of material and stress corrosion cracking in the RCS components exposed to reactor coolant (BWRVIP 1994). The guidelines recommend that the concentration of chlorides, sulfates, and dissolved oxygen be monitored daily and kept below the recommended levels to mitigate corrosion. The guidelines also recommend that the coolant conductivity and the electrochemical potential be monitored and kept below the recommended levels to mitigate SCC and corrosion in BWR plants. In certain cases, select components are to be inspected to verify the effectiveness of the chemistry control program and to ensure that significant degradation is 
not occurring and that the components intended function will be maintained during the extended period of operation.

Programs for Reactor Vessel Components. These programs manage loss of material and crack initiation and growth in low-alloy steel reactor vessel components, including vessel head closure studs, the feedwater nozzle, and the CRDRL nozzle (BWRVIP 1999c). The reactor head closure studs program includes visual, surface and volumetric examinations to detect crack initiation and growth due to SCC, loss of material due to wear, and reactor coolant leakage. The program is applicable to closure studs constructed from materials with a maximum tensile strength limited to less than 1,172 MPa (170 ksi) (USNRC 1973). Relevant field experience includes stress corrosion cracking of two studs exposed to oxygenated BWR coolant during bolt-up operation. The yield strength of the failed stud material was in the range of 965 to $1170 \mathrm{MPa}$ (Stoller 1991).

The BWR feedwater nozzle is subject to two aging effects due to fatigue: (1) cumulative fatigue damage caused by long-term, low-cycle thermal and mechanical fatigue, which affects the entire vessel including the nozzle wall, and (2) growth of existing cracks that were caused by high-cycle thermal fatigue resulting from turbulent mixing of relatively cool leaking feedwater with hot downcomer flow, which only affects the inner surface of the feedwater nozzle (USNRC 1980a, 1981). The modifications of the feedwater nozzle performed during the early 1980 s have eliminated the high-cycle thermal fatigue of the nozzle; no cracking of the feedwater nozzle due to high-cycle thermal fatigue has been reported for the last 15 years. Therefore, these two aging effects can be managed separately. Managing cumulative fatigue damage is discussed later in the paper. Managing the growth of existing cracks is discussed next.

The BWR feedwater nozzle program provides NRC-approved, BWR Owners Group inspection methods to manage the growth of existing cracks due to rapid thermal cycling, in accordance with the requirements of 10 CFR 54.21(c)(1)(iii) (BWROG 1999). These inspection methods require fracture mechanics analysis to estimate the growth of an assumed crack in the feedwater nozzle with an initial crack depth of $\sim 6 \mathrm{~mm}$, the size of a crack initiated by rapid thermal cycling before it was arrested. The analysis used the expected number of plant operation cycles during the current 40-year licensed operating period to determine the crack growth. The results from the fracture mechanics analysis were used to determine the inspection interval, not whether the crack growth at the end of the licensed operating period is acceptable.

The BWR CRDRL nozzle program includes enhanced ISI to detect cracking in accordance with the recommendations of NUREG0619 (USNRC 1980a). The relatively cool water passing through the CRDRL nozzle turbulently mixed with hot downcomer flow and caused cracking on the inside surface of the nozzle and also on the wall of the reactor pressure vessel beneath the nozzle at several BWR plants. The CRDRL nozzles have been capped at all but two BWR plants to eliminate this high-cycle thermal fatigue load. No cracking of the CRDRL nozzle has been reported since implementation of this AMP about 20 years ago.

Programs for Austenitic Stainless Steel Components. These programs manage crack initiation and growth due to SCC in vessel ID attachment welds and penetrations, vessel internals, and RCS piping. The programs provide guidelines for inspection and flaw evaluation, mitigation of stress corrosion cracking, and repair and replacement of damaged components. These guidelines are in addition to the ASME Section XI inspection requirements and/or flaw acceptance criteria. The programs also provide guidelines for evaluation of crack growth in stainless steels, nickel alloys, and low-alloy steels based on, respectively, BWRVIP-14, -59 , and -60 reports (BWRVIP 1998c, 1998d, 1999a). The guidelines of BWRVIP-62 may be used for inspection relief involving the components made of austenitic stainless steel and nickel-base alloys exposed to reactor coolant with hydrogen injection (BWRVIP 1998e). These reports have been reviewed or are being reviewed by NRC staff. The programs comply with the recommendations of the NRC staff presented in the corresponding final safety analyses reports.

The BWR vessel ID attachment welds program includes ISI and flaw evaluation of the attachment welds in accordance with the guidelines of BWRVIP-48 (BWRVIP 1998a). The guidelines recommend an enhanced visual VT-1 examination of the welds that is more stringent than the ASME Section XI VT-1 examination. Because the Section XI VT-1 examination has been found insufficient to detect tight intergranular SCC cracks, the enhanced VT-1 is now recommended to inspect BWR vessel internals. The enhanced VT-1 uses a camera able to detect 0.0005 -in. $(0.0013-\mathrm{cm})$ diameter stainless steel wire placed on the surface of a mockup of an internal component (e.g., core shroud) under water.

The Alloy 182 attachment welds with high residual and applied stresses, as well as a high electrochemical potential, are susceptible to IGSCC. A limited analysis of a BWR plant showed that the instrument nozzle welds have the highest residual tensile stresses, the jet pump riser brace arms have the highest applied tensile stresses, and the instrument nozzle welds and the attachment welds for the steam dryer support brackets have the highest electrochemical potential (Brown et al. 1991).

The BWR penetrations program includes inspection and evaluation to monitor SCC in the reactor vessel instrument penetrations and the standby liquid control (SLC) system nozzle or housing, including safe ends made of austenitic stainless steel or nickel alloys. The inspection and evaluation guidelines are in accordance with BWRVIP-49 and BWRVIP-27 (BWRVIP 1998b, 1997a).

The BWR vessel internals program provides guidelines for managing crack initiation and growth due to SCC, IGSCC, and irradiation-assisted stress corrosion cracking (IASCC) in safety-related vessel internals, e.g. core spray lines and sparger, core plate, top guide, shroud and its support, jet pump assemblies, low-pressure coolant injection coupling (LPCI), and BWR lower plenum, including control rod drive housings $(\mathrm{CRDH})$. This AMP manages the effects of SCC in the BWR vessel components and internals listed in Table 1.

The guidelines recommend enhanced visual VT-1 examinations or ultrasonic inspection methods for selected vessel internals and locations. The nondestructive examination (NDE) techniques appropriate for inspection of BWR vessel internals and their implementation needs, including the uncertainties inherent in delivering and executing NDE techniques in a BWR, are discussed in BWRVIP-03 (BWRVIP 1999b). The program comprehensively reviews the operating experience to identify the vessel internals susceptible to cracking, as illustrated by the following examples. 
TABLE 1. BWR Components and Inspection and Flaw Evaluation

\begin{tabular}{lll}
\hline Component & BWRVIP Report & Reference \\
\hline Core spray lines and spargers & BWRVIP-18 & BWRVIP 1996a \\
Core support plate & BWRVIP-25 & BWRVIP 1996b \\
Top guide & BWRVIP-26 & BWRVIP 1996c \\
Shroud support & BWRVIP-38 & BWRVIP 1997b \\
Jet pump assemblies & BWRVIP-41 & BWRVIP 1997c \\
LPCI coupling & BWRVIP-42 & BWRVIP 1997d \\
$\begin{array}{l}\text { CRDH stub tubes and guide tubes, In-core instrument } \\
\text { housing dry tubes and guide tubes } \\
\text { Vessel ID attachment welds }\end{array}$ & BWRVIP-47 & BWRVIP 1997e \\
Shroud & BWRVIP-48 & BWRVIP 1998a \\
\hline
\end{tabular}

Intergranular stress corrosion cracking of core shrouds and other vessel internals has been reported in NUREG-1544 (USNRC 1996b). Extensive cracking has been observed in shroud welds. This degradation has affected shrouds fabricated from Type 304 and Type 304L SS; the latter material, is generally considered to be more resistant to SCC (USNRC 1994a, 1994b, 1997b). Cracking in top guides has also been reported (USNRC 1995).

Cracking of core plates has not been reported, but the creviced regions beneath the plate are difficult to inspect. Instances of cracking has occurred in the jet pump assembly (USNRC 1980b), core spray spargers (USNRC 1980c), hold-down beam (USNRC 1993), and jet pump riser pipe elbows (USNRC 1997a). Intergranular cracking of dry tubes has been observed in 14 or more BWRs, including ones having no apparent sensitization, suggesting that IASCC (and possibly crevice geometry) may also play a role in the cracking (Brown and Gordon 1987).

The BWR stress corrosion cracking program includes inspection and flaw evaluation to monitor IGSCC in austenitic stainless steel piping with 4 -in. $(10-\mathrm{cm})$ or greater nominal diameter, that has been exposed to reactor coolant at a temperature of $93^{\circ} \mathrm{C}$ or higher during operation (USNRC 1988a, Hazelton and Koo 1988). The program also applies to pump casings, valve bodies and reactor vessel attachments and appurtenances, such as head spray and vent components. The inspection and evaluation guidelines are in accordance with the NRC GL 88-01 program or its recently modified version described in BWRVIP-75 (BWRVIP 1999d). The preventive activities recommended for the GL-88-01 program have been effective; no IGSCC cracking has been reported in the recirculation piping for more than ten years.

Programs for CASS Components. The thermal aging embrittlement of cast austenitic stainless steel program augments the ASME Section XI ISI requirements to detect the effects of loss of fracture toughness due to thermal aging in the CASS RCS piping with service temperatures above $250^{\circ} \mathrm{C}$.
The program involves determining the susceptibility of this piping to thermal aging embrittlement, and defines enhanced volumetric examination or flaw tolerance evaluation needed for "potentially susceptible" components. Among the piping and fittings constructed from CASS Grades CF-3, CF-3A, CF-8, and CF-8A, which have low-molybdenum content ( 0.5 wt. $\%$ max.), only static-cast steels with $>20 \%$ ferrite are potentially susceptible to thermal embrittlement. Among the piping components constructed from CASS Grades CF-3M, CF-3MA, and CF-8M, which have highmolybdenum content ( 2.0 to 3.0 wt.\% max.), static-cast steels with $>14 \%$ ferrite and centrifugal-cast steels with $>20 \%$ ferrite are potentially susceptible to thermal embrittlement (Chopra 1994). The ferrite content is calculated by using the Hull's equivalent factors and accounting for $\pm 6 \%$ deviation between measured and calculated values. A fracture toughness value of $255 \mathrm{~kJ} / \mathrm{m}^{2}$ at a crack depth of $2.5 \mathrm{~mm}(0.1$ in.) is used to differentiate between the CASS piping components that are potentially susceptible and those that are resistant to thermal embrittlement (Grimes 2000). The ASME Section XI inspection requirements are sufficient for managing the effects of loss of fracture toughness due to thermal embrittlement of CASS recirculation pump casing and valve bodies. Screening of these components for susceptibility to thermal aging is not required.

The program also provides enhanced inspection of potentially susceptible piping components because ASME Section XI ISI does not include volumetric inspection of the CASS base metal. This enhanced inspection includes use of examination methods that meet the criteria of the ASME Section XI, Appendix VIII. Alternatively, flaw tolerance may be evaluated to demonstrate that the thermally embrittled material has adequate toughness. Flaw evaluation for components with ferrite content up to $25 \%$ is performed according to the principles associated with IWB-3640 procedures for submerged arc welds (Lee, et al, 1997). Components with ferrite content greater than $25 \%$ are evaluated for flaws on a case-by-case basis, using fracture toughness data provided by the applicant. 
The thermal aging and neutron irradiation embrittlement of CASS program augments the requirements of ASME Section XI visual examination. Its purpose is to detect the effects of loss of fracture toughness due to thermal aging and neutron irradiation in the CASS vessel internals (i.e., orificed fuel supports and castings in jet pump assemblies). The screening criteria for the CASS internals susceptible to thermal aging are the same as the ones defined for the CASS piping. The CASS internals that have neutron fluence greater than $10^{17} \mathrm{n} / \mathrm{cm}^{2}$ $(\mathrm{E}>1 \mathrm{MeV})$ are considered to be susceptible to neutron irradiation embrittlement. Supplemental or enhanced inspection or a componentspecific flaw evaluation is required for the CASS internals susceptible to either thermal aging or neutron irradiation embrittlement. The supplemental inspection may include, for example, enhanced visual examination under the conditions of the in-service examination bounded by those used to demonstrate the resolution of the inspection technique. The component-specific evaluation includes assessment of mechanical loading to determine the maximum tensile loading on the component during ASME Level A, B, C, and D conditions. If loading is low enough $(<5 \mathrm{ksi})$ or compressive to preclude fracture, then supplemental examination is not required. The existing ASME Section XI inspection requirements are adequate for the CASS internals that are not susceptible to either thermal aging or neutron irradiation embrittlement.

Programs for Carbon Steel Piping and Closure Bolting. The flow-accelerated corrosion program described by the EPRI guidelines in the Nuclear Safety Analysis Center (NSAC)-202L-R2 includes procedures or administrative controls to ensure that the structural integrity of carbon steel components (i.e., main steam line, feedwater line, and valve bodies) in the BWR reactor coolant system is maintained. The program provides for (a) an analysis of wall thinning (i.e., loss of material) to determine critical locations, (b) limited baseline inspections to determine the extent of wall thinning at these locations, and (c) follow-up inspections to confirm the predictions, and replace components as necessary. The program also includes the use of the predictive code CHECWORKS to ensure that all the wall thinning caused by flow-accelerated corrosion is properly managed. This is a condition monitoring program, but it does refer to mitigative and preventive activities, which include monitoring water chemistry to control $\mathrm{pH}$ and dissolved oxygen content, and selection of appropriate piping material and configuration.

The bolting integrity program relies on the USNRC and industry recommendations and guidelines for material selection and testing, bolting preload control, inservice inspection, plant operation and maintenance, and evaluation of the structural integrity of bolted joints for safety-related bolting and structural bolting (USNRC 1990, EPRI 1988). The program covers closure bolting for the recirculation pump and valves as part of the BWR reactor coolant system. NUREG-1339 (USNRC 1990) indicates that the bolting material with yield strength greater than $150 \mathrm{ksi}$ is susceptible to SCC. For high strength bolting, the effects of cyclic loading are generally seen in conjunction with SCC in causing crack initiation and growth. The program notes that hot torquing of bolting is a leak preventive measure once the joint is brought to operating temperature (EPRI 1995). The program monitors for loss of material due to wear and loss of preload due to relaxation. ASME Section XI specifies both volumetric and visual examinations for bolting greater than $2-i n .(5-\mathrm{cm})$ diameter, and visual examinations alone for bolting smaller than 2-in. $(5-\mathrm{cm})$ diameter. The inspection schedules of ASME Section XI are effective in ensuring timely detection of leakage.
Metal Fatigue of Reactor Coolant Pressure Boundary. This program monitors and tracks the number of critical thermal and pressure transients for selected BWR RCS components. The program addresses the effect of the reactor coolant environment on a sample of critical components that includes, as a minimum, the components selected in NUREG/CR-6260. The selected BWR RCS components include the reactor vessel shell and lower head, reactor-vessel feedwater nozzle, reactor recirculation piping (including inlet and outlet nozzles), core spray line nozzle for the reactor vessel and associated Class 1 piping, RHR Class 1 piping, and feedwater line Class 1 piping (Ware et al.1995). The sample of critical components can be evaluated by applying environmental correction factors to the existing ASME Code fatigue analyses. Formulas for calculating the environmental correction factors are contained in NUREG/CR-6583 for carbon and low-alloy steels and in NUREG/CR-5704 for austenitic stainless steels (Chopra 1998, 1999). Acceptable corrective actions include a more rigorous analysis of the component to demonstrate that the usage factor will not exceed the design code limit, repair, or replacement of the component. If the program results indicate high fatigue usage factors for the monitored locations, additional sites on the reactor coolant pressure boundary are evaluated.

\section{Plant-Specific Aging Management Programs}

The GALL report recommends further evaluation of five plantspecific AMPs for the BWR RCS components:

(1) The reactor vessel surveillance program monitors loss of fracture toughness in the vessel beltline materials and the water-level instrument nozzle, if made of low alloy steel. If an applicant has a surveillance program that involves capsules with a projected fluence exceeding the 60 -year fluence at the end of 40 years, the applicant withdraws one capsule at an outage in which the capsule receives the equivalent of the 60-year neutron fluence and tests the capsule in accordance with the requirements of ASTM E 185 (ASTM 1988). (All pulled and tested capsules, if not discarded before August 31, 2000, are placed in storage for future reconstitution, in case the surveillance program is reestablished.) If all surveillance capsules have been removed by the end of the initial license period, restrictions are to be established to ensure that the plant is operated under conditions to which the surveillance capsules were exposed, and the exposure conditions of the reactor vessel are monitored to ensure that they continue to be consistent with those used to project the effects of embrittlement to the end of license. In addition, applicants without in-vessel capsules must use alternative dosimetry methods to monitor neutron fluence during the period of extended operation. If future plant operations exceed the limitations or bounds specified in NRC RG 1.99, Rev. 2 (USNRC 1988c), or derived from surveillance data related to embrittlement, the impact of plant operation changes on the extent of reactor vessel embrittlement must be evaluated, and the NRC be notified. An applicant without capsules in its reactor vessel is to reestablish the reactor vessel surveillance program to assess the extent of embrittlement. This program could be a plant-specific or an integrated surveillance program (BWRVIP 1999f).

(2) A plant-specific program for managing crack initiation and growth due to stress corrosion cracking in the vessel flange leak detection line. The existing programs may not be able to mitigate or detect crack initiation and growth due to SCC of this component.

(3) A plant-specific program for managing crack initiation growth due to cyclic loading in the jet pump sensing line. 
(4) A plant-specific program for managing crack initiation and growth due to SCC and cyclic loading and loss of material due to corrosion in the isolation condenser stainless steel and carbon steel components (i.e., tubing, tube sheet, channel head, and shell). This program augments the ASME Section XI program and provides verification of the effectiveness of the program to ensure that significant degradation is not occurring. An acceptable verification program includes temperature and radioactivity monitoring of the shell side water, and eddy current testing of tubes.

(5) A plant-specific destructive or nondestructive examination that permits inspection of the inside surfaces of piping to ensure that cracking has not occurred. The ASME Section XI program does not require volumetric examination of Class 1 piping and fittings less than NPS 4, which have experienced crack initiation and growth due to stress corrosion cracking and thermal and mechanical cyclic loadings (USNRC 1988d). This inspection program provides for verifying that service-induced weld cracking is not occurring in the small-bore piping. One-time inspection is an acceptable verification method to confirm that crack initiation and growth is not occurring in the small-bore piping. When an aging effect is revealed by a one-time inspection, the routine evaluation of the inspection results would identify appropriate corrective actions.

\section{CONCLUSIONS}

This paper summarizes the findings of the GALL report, which systematically evaluated the generic AMPs for the BWR RCS components. The AMPs incorporate, through reference, the state-ofthe-art mitigative and preventive techniques, nondestructive examination methods, and crack growth models. The programs are based on a comprehensive review of the field experience. It was found that several AMPs need enhancement to more effectively manage certain aging effects during a plant's extended period of operation. The GALL report has recommended aging management activities that will verify the effectiveness of these AMPs during a plant's extended operation. The use of the GALL report should facilitate both preparation of a license renewal application and timely and uniform review by the NRC staff.

\section{ACKNOWLEDGMENTS}

The authors would like to acknowledge the support of the U.S. Nuclear Regulatory Commission. Numerous NRC staff have reviewed and commented on the GALL report. The authors would also like to acknowledge the contribution of Dr. Omesh Chopra in preparing the portion of the GALL report related to aging management of the BWR RCS components.

\section{REFERENCES}

10 CFR 54 2000. "Requirements for Renewal of Operating Licenses for Nuclear Power Plants," Office of the Federal Register, National Archives and Records Administration, 2000.

ASME 1995. Rules for In-service Inspection of Nuclear Power Plant Components, ASME Boiler and Pressure Vessel Code, ASME Section XI, 1995 edition through the 1996 addenda, American Society of Mechanical Engineers, New York, NY.

ASTM 1988. "Standard Recommended Practice for Surveillance Tests for Nuclear Reactor Vessels," Annual Book of ASTM Standards, ASTM E-185-82, Vol. 12.02, American Society for Testing Materials, Philadelphia, PA, 1988.
Brown, K. S., et al. 1991. Reactor Pressure Vessel Attachment Welds: Degradation Assessment, EPRI NP-7139-D, Electric Power Research Institute, Palo Alto, 1991.

Brown, K. S., and Gordon, G. M. 1987. "Effects of BWR Coolant Chemistry on the Propensity for IGSCC Initiation and Growth in Creviced Reactor Internals Components," Third International Symposium on Environment Degradation of Materials in Nuclear Power Systems-Water Reactors, Traverse City, Michigan, August 30September 3, 1987, National Association of Corrosion Engineers, Houston, pp. 243-247, 1987.

BWROG 1999. Alternate BWR Feedwater Nozzle Inspection Requirements, GE-NE-523-A71-0594, Rev. 1, BWR Owner's Group, August 1999.

BWRVIP 1994. BWR Vessel and Internals Project, BWR Water Chemistry Guidelines-1993 Revision, Normal and Hydrogen Water Chemistry, BWRVIP-29, EPRI TR-103515, Electric Power Research Institute, Palo Alto, CA, February 1994.

BWRVIP 1996a. BWR Vessel and Internals Project, BWR Core Spray Internals Inspection and Flaw Evaluation Guidelines, BWRVIP-18, EPRI TR-106740, Electric Power Research Institute, Palo Alto, CA, July 1996.

BWRVIP 1996b. BWR Vessel and Internals Project, BWR Core Plate Inspection and Flaw Evaluation Guidelines, BWRVIP-25, EPRI TR107284, Electric Power Research Institute, Palo Alto, CA, December 1996.

BWRVIP 1996c. BWR Vessel and Internals Project, Top Guide Inspection and Flaw Evaluation Guidelines, BWRVIP-26, EPRI TR107285, Electric Power Research Institute, Palo Alto, CA, December 1996.

BWRVIP 1997a. BWR Vessel and Internals Project, BWR Standby Liquid Control System/Core Plate P Inspection and Flaw Evaluation Guidelines, BWRVIP-27, EPRI TR-107286, Electric Power Research Institute, Palo Alto, CA, April 1997.

BWRVIP 1997b. BWR Vessel and Internals Project, BWR Shroud Support Inspection and Flaw Evaluation Guidelines, BWRVIP-38, EPRI TR-108823, Electric Power Research Institute, Palo Alto, CA, September 1997.

BWRVIP 1997c. BWR Vessel and Internals Project, BWR Jet Pump Assembly Inspection and Flaw Evaluation Guidelines, BWRVIP-41, EPRI TR-108728, Electric Power Research Institute, Palo Alto, CA, October 1997.

BWRVIP 1997d. BWR Vessel and Internals Project, BWR LPCI Coupling Inspection and Flaw Evaluation Guidelines, BWRVIP-42, EPRI TR-108726, Electric Power Research Institute, Palo Alto, CA, December 1997.

BWRVIP 1997e. BWR Vessel and Internals Project, BWR Lower Plenum Inspection and Flaw Evaluation Guidelines, BWRVIP-47, EPRI TR-108727, Electric Power Research Institute, Palo Alto, CA, December 1997. 
BWRVIP 1998a. BWR Vessel and Internals Project, Vessel ID Attachment Weld Inspection and Flaw Evaluation Guidelines, BWRVIP-48, EPRI TR-108724, Electric Power Research Institute, Palo Alto, CA, February 1998.

BWRVIP 1998b. BWR Vessel and Internals Project, Instrument Penetration Inspection and Flaw Evaluation Guidelines, BWRVIP-49, EPRI TR-108695, Electric Power Research Institute, Palo Alto, CA, March 1998.

BWRVIP 1998c. Evaluation of Crack Growth in BWR Stainless Steel RPV Internals, BWRVIP-14, EPRI TR-105873, Electric Power Research Institute, Palo Alto, CA, March 18, 1996, and as amended on November 24, 1998.

BWRVIP 1998d. Evaluation of Crack Growth in BWR Nickel-Base Austenitic Alloys in RPV Internals, BWRVIP-59, EPRI TR-108710, Electric Power Research Institute, Palo Alto, CA, December 23, 1998.

BWRVIP 1998e. BWR Vessel and Internals Project, Technical Basis for Inspection Relief for BWR Internal Components with Hydrogen Injection, BWRVIP-62, EPRI TR-108705, Electric Power Research Institute, Palo Alto, CA, December 31, 1998.

BWRVIP 1999a. BWR Vessel and Internals Project, Evaluation of Crack Growth in BWR Low Alloy Steel RPV Internals, BWRVIP-60, EPRI TR-108709, Electric Power Research Institute, Palo Alto, CA, March 30, 1999.

BWRVIP 1999b. BWR Vessel and Internals Project, Reactor Pressure Vessel and Internals Examination Guidelines, BWRVIP-03, EPRI TR105696 R1, Electric Power Research Institute, Palo Alto, CA, March 30,1999

BWRVIP 1999c. BWRVIP Vessel and Internals Project, BWR Reactor Pressure Vessel Inspection and Flaw Evaluation Guidelines, BWRVIP-74, EPRI TR-113596, Electric Power Research Institute, Palo Alto, CA, September 1999.

BWRVIP 1999d. Technical Basis for Revisions to Generic Letter 8801 Inspection Schedules (NUREG-0313), BWRVIP-75, EPRI TR113932, Electric Power Research Institute, Palo Alto, CA, October 1999.

BWRVIP 1999e. BWR Vessel and Internals Project, BWR Core Shroud Inspection and Flaw Evaluation Guidelines, BWRVIP-76, EPRI TR-114232, Electric Power Research Institute, Palo Alto, CA, November 1999.

BWRVIP 1999f. BWR Vessel and Internals Project, BWR Integrated Surveillance Program Plan, BWRVIP-78, EPRI TR-114228, Electric Power Research Institute, Palo Alto, CA, December 1999.

Chopra, O., 1994. Estimation of Fracture Toughness of Cast Stainless Steels During Thermal Aging in LWR Systems, NUREG/CR-4513, Rev. 1, U.S. Nuclear Regulatory Commission, August 1994.

Chopra, O. and W.J. Shack, 1998. Effects of LWR Coolant Environments on Fatigue Design Curves of Carbon and Low-Alloy Steels, NUREG/CR-6583, U.S. Nuclear Regulatory Commission, March 1998
Chopra, O., 1999. Effects of LWR Environments on Fatigue Design Curves for Austenitic Stainless Steels, NUREG/CR-5704, U.S. Nuclear Regulatory Commission, April 1999.

EPRI 1988. Degradation and Failure of Bolting in Nuclear Power Plants, Volumes 1 and 2, EPRI NP-5769, Electric Power Research Institute, Palo Alto, CA, April 1988

EPRI 1995. Bolted Joint Maintenance \& Application Guide, EPRI TR104213, Electric Power Research Institute, Palo Alto, CA, April 1995.

Grimes, C. I., 2000. License Renewal Issue No. 98-0030, Thermal Aging Embrittlement of Cast Stainless Steel Components, NRC Letter to D. J. Walters, Nuclear Energy Institute, May 19, 2000.

Hazelton, W. S., and W. H. Koo 1988. Technical Report on Material Selection and Processing Guidelines for BWR Coolant Pressure Boundary Piping, NUREG-0313, Rev. 2, U.S. Nuclear Regulatory Commission, 1988.

Lee, S., P. T. Kuo, K. Wichman, and O. Chopra 1997. "Flaw Evaluation of Thermally Aged Cast Stainless Steel in Light-Water Reactor Applications," Int. J. Pres. Ves. \& Piping, 72, pp. 37-44, 1997.

Stoller (S. M. Stoller Corporation) 1991. "Reactor Head Closure Studs Cracking, Material Toughness Outside FSAR - SCC in Threads Root," Nuclear Power Experience, BWR-2, III, 58, p. 30, 1991.

USNRC 1973. Material and Inspection for Reactor Vessel Closure Studs, NRC Regulatory Guide 1.65, U.S. Nuclear Regulatory Commission, October 1973

USNRC 1980a. BWR Feedwater Nozzle and Control Rod Drive Return Line Nozzle Cracking, NUREG-0619, U.S. Nuclear Regulatory Commission, November 1980.

USNRC 1980b. BWR Jet Pump Assembly Failure, NRC IE Bulletin No. 80-07, U.S. Nuclear Regulatory Commission, April 4, 1980 (Supplement 1, May 13, 1980)

USNRC 1981. All Power Reactor Licensees and License Applicants, NRC Generic Letter 81-11, U.S. Nuclear Regulatory Commission, February 29, 1981.

USNRC 1988a. NRC Position on IGSCC in BWR Austenitic Stainless Steel Piping, NRC Generic Letter 88-01, U.S. Nuclear Regulatory Commission, January 25, 1988 (Supplement 1, February 4, 1992).

USNRC 1988b. Cracks in Shroud Support Access Hole Cover Welds, NRC Information Notice 88-03, U.S. Nuclear Regulatory Commission, February 2, 1988.

USNRC 1988c. Radiation Embrittlement of Reactor Vessel Materials, NRC Regulatory Guide 1.99, Rev. 2, U.S. Nuclear Regulatory Commission, 1988.

USNRC 1988d. Thermal Stresses in Piping Connected to Reactor Coolant System, NRC Bulletin 88-08, U.S. Nuclear Regulatory Commission, 1988 (Supplement 1, 1988; Supplement 2, 1988; Supplement 3, 1989). 
USNRC 1990. Resolution of Generic Safety Issue 29: Bolting Degradation or Failure in Nuclear Power Plants, NUREG-1339, U.S. Nuclear Regulatory Commission, June 1990.

USNRC 1992. Radial Cracking of Shroud Support Access Hole Cover Welds, NRC Information Notice 92-57, U.S. Nuclear Regulatory Commission, August 11, 1992.

USNRC 1993. Jet Pump Hold-Down Beam Failure, NRC Information Notice 93-101, U.S. Nuclear Regulatory Commission, December 17, 1993.

USNRC 1994a. Cracking in the Lower Region of the Core Shroud in Boiling Water Reactors, NRC Information Notice 94-42, U.S. Nuclear Regulatory Commission, June 7, 1994.

USNRC 1994b. Intergranular Stress Corrosion Cracking of Core Shrouds in Boiling Water Reactors, NRC Generic Letter 94-03, U.S. Nuclear Regulatory Commission, July 25, 1994.

USNRC 1995. Reactor Vessel Top Guide and Core Plate Cracking, NRC Information Notice 95-17, U.S. Nuclear Regulatory Commission, March 10, 1995.

USNRC 1996a. Summary of Technical Information and Agreements from Nuclear Management and Resource Council Industry Reports Addressing License Renewal, NUREG-1557, U.S. Nuclear Regulatory Commission, October 1996.
USNRC 1996b. Status Report: Intergranular Stress Corrosion Cracking of BWR Core Shrouds and Other Internal Components, NUREG-1544, U.S. Nuclear Regulatory Commission, March 1996.

USNRC 1997a. Cracks Found in Jet Pump Riser Assembly Elbows at Boiling Water Reactors, NRC Information Notice 97-02, U.S. Nuclear Regulatory Commission, February 6, 1997.

USNRC 1997b. Cracking of Vertical Welds in the Core Shroud and Degraded Repair, NRC Information Notice 97-17, U.S. Nuclear Regulatory Commission, April 4, 1997.

USNRC 2001a. Generic Aging Lessons Learned (GALL) Report, U.S. Nuclear Regulatory Commission, NUREG-1801, April 2001.

USNRC 2001b. Standard Review Plan for Review of License Renewal Applications for Nuclear Power Plants, U.S. Nuclear Regulatory Commission, NUREG-1800, April 2001.

Ware, A. G., D. K. Morton, and M. E. Nitzel 1995. Application of NUREG/CR-5999 Interim Fatigue Curves to Selected Nuclear Power Plant Components, NUREG/CR-6260, INEL-95/0045, March 1995. 